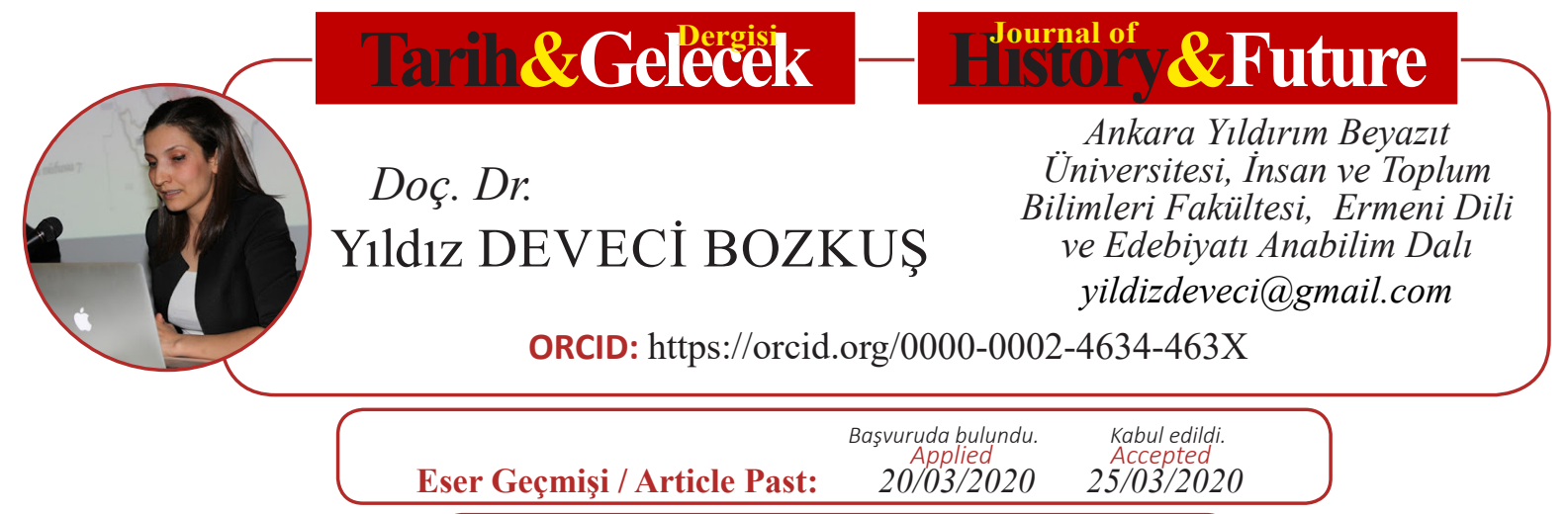

DOI: http://dx.doi.org/10.21551/jhf.707963

Research Paper

Orjinal Makale / Orginal Paper

\title{
Sicill-i Ahval Kayıtlarına Göre Afyonkarahisar Doğumlu Ermeni Memurlar
}

\author{
According to the Registration Circumstances in the XIX. Century \\ the Armenian Officials in Afyonkarahisar
}

$\ddot{\mathbf{O z}}$

Bu çalışmada genel hatlarılla XIX. yüzyılda Osmanlı Imparatorluğu'nda Afyonkarahisar Sancă̆ı'nda yaşamış ve devletin resmi görevlerinde bulunmuş Ermeni şahsiyetler üzerinde durulacaktır. XIX. Yüzyıldan itibaren Devletin hemen hemen her alanında Ermeni memurlar daha yoğun bir biçimde görev almaya başlamıștır. Bu noktada bilindiği üzere Afyonkarahisar da tarihsel süreçte Ermeni nüfusunun yoğun olarak yaşamış olduğu önemli şehirlerden biridir. Bu nedenle bu çalışmada buradaki Ermeni nüfusunun bölgenin demografik yapısı içerisindeki yeri üzerinde durulacaktır. Ilk etapta şehrin tarihsel arka planına kısaca yer verildikten sonra buradaki Ermeni yerleșimlerinin tarihsel geçmişi üzerinde durulacaktır. Bu çerçevede bölgedeki Ermeni dini mekanları, mezartaşlart, yerleşim yerleri v $b$. mekanlara dair bilgiler verilecektir. XIX. yüzyılda Afyonkarahisar'da Ermeni nüfusunun genel durumunun da inceleneceği bu çalışmada genel itibariyle Sicill-i Ahval Defterleri'nden yararlanılacaktır. Sicill-i Ahval Defterleri'nden hareketle XIX. yüzyılda Afyonkarahisar'da görev yapan Ermeni memurlarının sayısı ve görev aldıkları kurumlar üzerinde de durulacaktır. Daha sonra bu memurların kimler olduğu ve hangi alanlarda görev aldıkları konularına da yer verilerek söz konusu memurların eğitimleri, görev aldıkları kurum ve memuriyetler ile aile bilgilerine de genel hatlartyla değinilecektir.

Anahtar Kelimeler: Ermeniler, Afyonkarahisar, Devlet Memurları, İstepan Efendi, Onnik Efendi

\begin{abstract}
Absract
In this study, in general terms in the Ottoman Empire Armenian officials who lived in XIX. Century in Afyonkarahisar and held official duties of the state will be emphasized. As it is known, Afyonkarahisar has been one of the important cities where the Armenian population densely lived in the historical process. Then, the place of the Armenian population in the demographic structure of the region will be emphasized. At this point, after briefly mentioning of the historical background of the city, this article will focus on the historical background of the Armenian settlements in here. In this study, which will examine the general situation of the Armenian population in Afyonkarahisar in the 19th century, in general, Sicill-i Ahval records will be used. Based on the Sicill-i Ahval records, the number of Armenian officials working in Afyonkarahisar in the XIX. century and their institutions will be emphasized. Then, the subjects of who these officers are and in which areas they are working will be discussed. The trainings received by civil servants, institutions they served and their family information will also be outlined in general.
\end{abstract}

Key Words: Armenians, Afyonkarahisar, Ottoman State Officials, İstepan Efendi, Onnik Efendi

ATIF: DEVECİ B. Yıldız., "Sicill-i Ahval Kayıtlarına Göre Afyonkarahisar Doğumlu Ermeni Memurlar", Tarih ve Gelecek Dergisi, 6/1 (Mart 2020), s. (13-25) 


\section{Giriş}

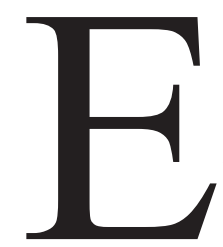

rmeniler tarihten günümüze, Osmanlı Devleti döneminde veya birçok kaynakta geçtiği adıyla Türk Devleti hizmetinde hemen hemen her alanda yer almış bir millet olmuştur. Bu noktada Devlet hizmetinde Ayan Azaları, Mebuslar, Hariciye Nazırları, Haziney-i Hassa Nazırı, Şuray-1 Devlet Üyeleri, Şehbenderhane Erkanı, Dahiliye Nezareti, Valilik, Nafia Nezareti, Orman ve Maâdin ve Zirâat Nezâreti, Posta Nezareti, Maliye Nezareti Maarif, Adalet, Basın, Mimari, Baruthane, Gümrük, Sanat, Ticaret, Hukuk, Müzik vb. alanlarda oldukça önemli görevlerde bulunmuşlardır. Bu görevlerde bulunan Ermenilerin çoğunun son derece donanımlı ve eğitimli oldukları ve Ermeni entelektüel sınıfını oluşturdukları bilinmektedir. ${ }^{1}$ Bu konuda Zeidner, Ermelerin Osmanlı Devleti içerisindeki resmi hizmetlerin üçte birini oluşturduklarını dahi kaydetmiştir. ${ }^{2}$

Özellikle Osmanlı Sultanlarının gayrımüslimlere yönelik yaklaşımlarının ve Ermenilere tanınan hakların ve onlara gösterilen itimadın da Ermenilerin İmparatorluğun her katmanında görev almalarında etkili olduğuna işaret edilir. Bu noktada benzer bir sürecin 17 yüzyılda Ermeni kültür ve hayatının önemli merkezlerinden olan İsfahan/Yeni Culfa ve 18 -19 yüzyıllarda ise Kalküta ve Tiflis'te de yaşandığını ancak bu merkezlerin hiçbirinin İstanbul'daki kadar güçlü bir etkiye sahip olmadığının altını çizer. ${ }^{3}$ Oshagan'a göre özellikle Kalküta 18 yüzyılda Ermeni modernleşme sürecinde oldukça sınırlı bir etkiye sahip olmuştur. ${ }^{4}$ Edmund Herzig'e göre Culfa' daki Ermeni tüccarlarının uluslararası ticaret ağı, 16 yüzyıldan 18 yüzyıla kadar geçen sürede dünya ekonomisindeki gelişmelerde önemli bir yere sahip olmuștur. Ermeni tüccarlarının bu etkilerinin 16 yüzyılın ikinci yarısına dayandığını kaydeden Herzig, aynı dönemlerde Avrupa'nın Asya ile ticari ilişkilerinin şekillenmesinde de tüccarların rolüne dikkat çeker. ${ }^{5}$

Yarman'a göre 18. Yüzyılın sonlarından itibaren amiralar Osmanlı Devletinde çok önemli görevlere yükselmiştir. Yarman 19. Yüzyılda 80'e yakın amira ailesinin Osmanlı Devletinde bulunduğunu ve bu amiraların kendilerini Ermeni soylu sınınfının en parlak örnekleri olan "nakharar"lara dayandırdıklarını kaydeder. Yarman söz konusu amiraların çoğunun Agn (Eğin) kökenli olan çok zengin sarraflardan oluştuğunu ve sultanların, vezirlerin, paşaların kişisel servetlerini yö-

1 Robert F. Zeidner, "Britain and the Launching of the Armenian Question", International Journal of Middle East Studies, 7(4), 1976, s.469, M.Sadi Koçaş, Tarihte Ermeniler ve Türk-Ermeni İlişkileri, Kastaş Yayınları, İstanbul, 1990, s.108-130, Mesrob K. Krikorian, Armenians in the Service of the Ottoman Empire: 1860-1908, Routledge, 1977, s.102-110. Bu konuda detaly bilgi için bkz: Hratch Kouyoumjian, Ethnic Armenian Civil Servants in the Ottoman Empire in 1909, Great Britain, 2015, s.8-57.

2 Zeidner, agm, s.469.

3 Boğos Levon Zekiyan, Ermeniler ve Modernite: Gelenek ve Yenileşme/Özgüllük ve Evrensellik Arasında Ermeni Kimliği, Aras Yayınları, İstanbul, 2001, s.9, Kevork Aslan, Armenia and The Armenians, Elibron Classics, New York, 2005, s.113.

4 Vahe Oshagan, "From Enlightenment to Renaissance: The Armenian Experience", Enlightenment and Diaspora, The Armenian and Jewish Cases, Edt: Richard G. Hovannisian and David N. Myers, Scholor Press, Atlanta, Georgia, 1999, s.176.

5 Edmund M. Herzig, The Armenian Merchants of New Julfa, Isfahan: A Study in Pre-modern Asian Trade. Oxford University, UK, 1991, s.270. 
nettiklerini de ifade eder. ${ }^{6}$ Osmanlı Devletinde amiralar ${ }^{7}$ olarak bilinen aristokrat Ermeni sınıfının, varlıklı ve etkili Ermeni elitlerden oluştuğu, Balian, Bezciyan, Dadyan ve Düzyan ailelerinin saltanat yönetimiyle yakın bir ilişkilerinin olduğu, onların himaye ve pozisyonlarını baltalayabilecek olası entellektüellere karşı muhalif oldukları da kaydedilmiştir. ${ }^{8}$

Tanzimat döneminin önde gelen kurucu isimleri olan Reşid, Rıza, Ali, Fuat ve Mithat Paşa'ların yurtdışı özellikle Londra ve Paris görevleri sırasında danışman, katip, tercüman ve elçilik göevlerinde büyük oranda Ermenilerin görev aldığ 1 bilinmektedir. Örneğin Reşid Paşa (1802-1857)'nın Paris'teki elçilik görevi sırasında Agop Gırcikyan Efendi (1806-1865) ve Krikor Ağaton'un (1825-1868) kendisiyle çalıştığı bilinmektedir. Hamamciyan ve Seferyan'ın Âli Paşaya, Sahak Abro'nun Fuat Paşa'ya, Vartan Paşa olarak da bilinen Hovsep Vartanyan'in Damat Mehmet Ali Paşa'nın danışmanı olduğu, Cevdet Paşa'nın danışmanlarından birinin de Vahan Efendi olduğu, Krikor Odyan'ın ise Mithat Paşa'ya danışmanlık yaptığı bilinmektedir. ${ }^{9}$

Araştırmacılara göre İmparatorluğun ekonomik süreçleri Doğu ve Batı'daki uzak siyasi devletlerle olan ticari ilişkiler ve Yunanlıların bağımsızlık savaşı Ermeni milletinin Devletteki pozisyonunda da etkili olmuş ve bu pozisyonu güçlendirmiştir. Böylece imparatorlukta çeşitli pozisyonlardaki, bölgesel yönetimler, diplomatlar, finansörler, girişimciler, sanatkârlar, ustalar, kâşifler, gıda satıcıları olan Ermeni ailelerinin sayıları da artmıştır. ${ }^{10}$

Osmanlı Devletinde aktif bir şekilde şehrin yeniden doğuşu ve varlıklı durumunun devam ettirilmesinde Ermenilerin aktif rol aldığına dikkat çeken Ronald T. Marchese \& Marlene R. Breu, sıradan Ermeni vatandaşlarının yanı sıra tüccar, girişimci, yaratıcı, usta, din adamı, bürokrat, balıkçı, hamal vb. Ermeni nüfusunun da şehrin kozmopolit yapısını etkilediğine dikkat çekmiştir. Bu yönüyle söz konusu Ermenilerin bir bakıma İstanbul'u etnik gruplar ve kültürel gelenekler mozaiği ve adeta Anadolu'nun minyatürü (küçük evreni) haline getirmişlerdir. ${ }^{11}$

Tüm bu veriler 1şığında XIX. yüzyılda Devletin birçok noktasında olduğu üzere Afyonkarahisar'da da Ermeni nüfusu Müslüman toplumla iç içe yaşamış ve burada da Ermeni toplumu Katolik, Protestan ve Gregoryen olmak üzere kendi mezheplerine ait dini mekânlarda ibadetlerini yerine getirmişlerdir. Afyonkarahisar'da Ermenilerin kendilerine ait ibadethanelerinin yanı sıra kız ve erkek çocukları için eğitim kurumları, vakıfları, evleri, konakları, mezarlıkları vb. alanlarının da olduğu bilgilerine Salnamelerdeki kayıtlardan ulaşmak mümkündür. ${ }^{12} \mathrm{Bu}$ verilerden

6 Arsen Yarman \& Ara Aginyan, Sultan II. Mahmut ve Kazaz Artin Amira. Surp Pirgiç Kültür Sanat Yayınlar1, İstanbul, 2013, s.280-281, Hagop Barsoumian, "The dual role of the Armenian Amira class within the Ottoman government and the Armenian millet (1750-1850)", Christians and Jews in the Ottoman Empire: the Functioning of a Plural Society, Haz: B. Braude \&B. Lewis, Cilt 1, Princeton University, New York-London, 1982, s. 171-184.

7 Arapça'daki amir (üst, kumandan, yönetici) sözcüğünden türetilen amira kelimesi Osmanlı Devletindeki çelebilerin ve hocaların düşüşünün ardından, 18 yüzyıl ortalarından itibaren Ermeni aristokrasisinin en üst tabakası için kulanılan bir ünvan olmuştur. Zekiyan, age, s.85.

8 R. G. Hovannisian, \& S. Payaslian, Armenian Constantinople, Mazda Publishers, USA, 2010, s.2-3, Benjamin Braude, \& Bernard Lewis (Eds.), Christians and Jews in the Ottoman Empire: The Functioning of a Plural Society (Vol. 2), Holmes \& Meier Pub., London, 1982, s.171.

9 Yervant G. Çark, Türk Devleti Hizmetinde Ermeniler, Kesit Yayınları, İstanbul, 1953, s.97-98, Vartan Artinian, Osmanlı Devleti'nde Ermeni Anayasası'nın Doğuşu 1839-1863, Aras Yayınları, İstanbul, 2004, s.92-93.

10 Ronald T. Marchese and Marlene R. Breu, “Intersection of Society, Culture and Religion”, Ed: Richard G. Hovannisian, \& S. Payaslian, Armenian Constantinople, USA: Mazda Publishers, 2010, s.116.

11 Marchese \& Breu, agm, s.102-103.

12 Yusuf Ilgar, “Afyonkarahisar Ermenilerinde Kültürel ve Dinî Hayat”, Sosyal Bilimler Dergisi, C. 7, S. 1, 2005, s.240-265. 
hareketle XIX. yüzyılda Osmanlı Devletinde Ermeni vatandaşlarının Afyonkarahisar'da Devlet hizmetinde de önemli görevlerde bulunduklarını söylemek mümkündür. Ancak Ermeni entelektüeller veya sanatkârların isimleri ürettikleri eserler aracılığıyla günümüze kadar ulaşabilmişken devlet hizmetinde görev almış resmi memurların ise memuriyetlerine dair veriler dışında günümüze yansıyabilecek çok fazla kayıtlar olmadığından diğer Ermeni aydınları kadar şanslı olmamışlardır. İşte bu çalışmanın amacı tamda bu soruya cevap aramakta ve Afyonkarahisar'da Devlet hizmetinde bulunmuş olan resmi görevlerdeki Ermeni memurların kimler olduğu, hangi görevlerde bulunduğu ve eğitimlerine dair önemli bilgileri gün yüzüne çıkarmayı ve bu şahsiyetlerin hayatlarını araştırmacıların dikkatine sunmayı hedeflemektedir. Söz konusu makalenin sınırları XIX. yüzyıl ve Sicill-i Ahval defterleriyle sınırlı olup bu hususa geçmeden önce kısaca tarihsel süreçte Afyonkarahisar'ın ve buradaki Ermenilerin demografik durumuna dair bazı bilgilerin verilmesinin yararlı olacağı öngörülmektedir.

\section{Tarihsel Süreçte Afyon'da Ermeniler}

Afyon bölgesine dair tespit edilen ilk sayım defteri olan 1528-29/H.935 tarihli tahrir defterine göre daha önce Fatih Sultan Mehmet ve II. Bâyezid dönemlerinde bölgede sayımlar yapılmıştır. $\mathrm{Bu}$ sayımlardan hareketle buradaki Ermeni nüfusuna dair en eski kaynakların XVI yüzyılı işaret ettiği görülmektedir. ${ }^{13}$

15 yüzyılda Afyonkarahisar'daki Ermeni nüfusla ilgili en önemli kaynaklar arasında vergi kayıtlarının geldiğini söylemek mümkündür. 1528 yılı kayıtlarına göre şehirde 94 olan gayrimüslim vergi mükellefinden 79'unun Ermeni olduğunu kaydeden Polat, 1572 yılındaki vergi kayıtlarında ise iki Ermeni mahallesinde 150 kişinin ikamet ettiğine işaret eder. ${ }^{14}$

Afyon'daki Ermeni nüfusunun oluşumuyla ilgili olarak Ermenilerin sanatlarından istifade etmek amacıyla İran seferinden sonra Sultan Dîvânî'nin aracılığgyla Afyonkarahisar'a yedi hane olarak geldikleri kaydedilmiştir. ${ }^{15}$ Antik Çağlar' dan günümüze toplumların sosyal yapılarının şekillenmesinde dinin önemli bir yeri olmuştur. Dini yapılar beraberinde toplumların yaşadıkları yerlerde ibadethane inşa etmelerinde de etkili olmuştur. Bu kapsamda Afyonkarahisar'da da Ermenilerin kullandığ1 ibadethane Meryem Ana Kilisesi olmuştur. Kalenin eteğinde ve şehrin en eski yerleşim bölgesinde yer alan bu kilisenin merkez alınarak Ermeni nüfusunun yerleştiği kaydedilmiştir. ${ }^{16}$ XVII. yüzyılda Polonyalı Simeon'un Afyonkarahisar'ı anlatırken şehirde 60 hane Ermeni ile taş bir kilisenin olduğunu, çeyrek mil uzakta bir Ermeni köyü ve burada da bir manastırın olduğuna dair bilgiler verir. ${ }^{17}$ Söz konusu kilisenin mevcudiyeti Ermeni nüfusunun dini ve sosyal yapısına dair de önemli ipuçları içermektedir. Nitekim Afyonkarahisar müzesinde tespit edilen Ermenice ve Ermeni harfli Türkçe mezar taşları da buradaki Ermeni yerleşimine ve nüfusuna dair önemli ipuçları barındırmaktadır.

\footnotetext{
13 Latif Daşdemir, "Afyonkarahisar"eda Türk Yerleșim ve Nüfusu”, Afyonkarahisar Kütüğü, C.I, AKÜ Yay., Afyon, 2001, s.253'den aktaran Zelkif Polat, Tanzimattan Tanzimat'tan Cumhuriyet'e Afyonkarahisar'da Ermengiler (1839-1923), Afyon Kocatepe Üniversitesi Yayınlanmamış Doktora Tezi, Afyonkarahisar, 2011, s.22.

14 Polat age, s.31.

15 Yusuf Ilgar, "Afyonkarahisar Ermenileri Üzerine Bir Deneme”. Yeni Türkiye, C. 60, 2014, s.1, Ömer Fevzi Atabek, Afyon Vilayeti Tarihçesi, Haz: Turan Akkoyun, AKÜ Yayınları, Afyon, 1997, s.119'dan aktaran Polat 2011, age, s.30.

16 Ilgar 2014, age, s.12, Polat 2011, age, s.30.

17 Polat 2011, s.23.
} 


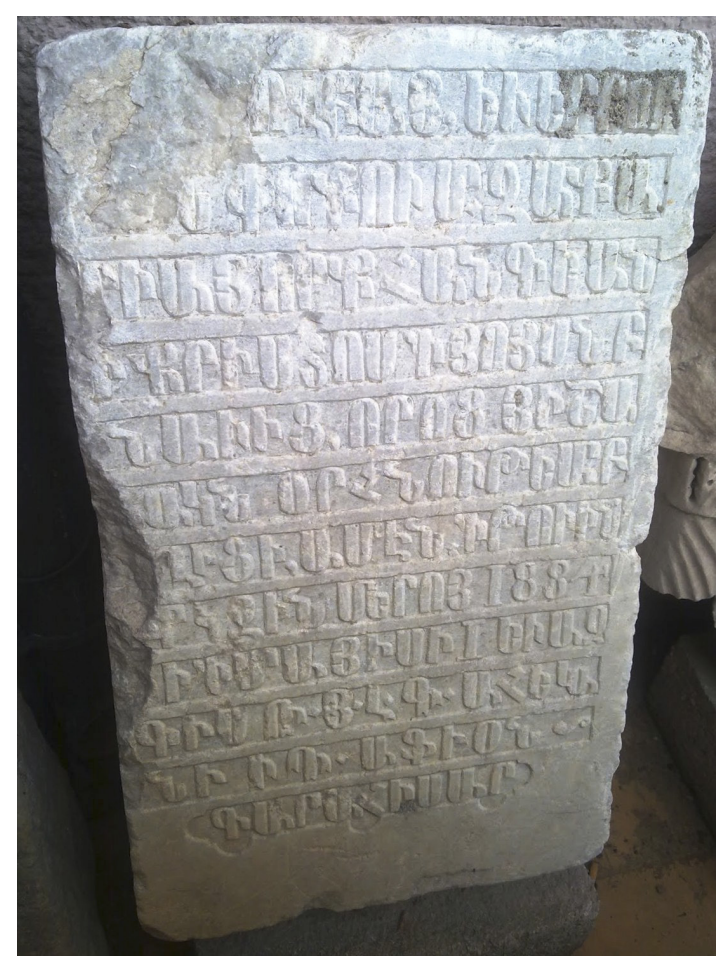

Resim 1: Afyonkarahisar Müzesindeki Ermenice Mezartaşlar1 ${ }^{18}$

\section{Türkçe Çevirisi}

1.Satır: ?OVBATS, EIERROR

2.Satır: ?POKUM ŞAKA.

3.Satır: ??? KRİSTOS 2NCİ İYOYAN

4.Satır: KRISTOS ???

5.Satır: ??? [HİŞA] [Y Harfi Batı Ermenicede Bazen H Harfi Olarak Okunur]

6.Satır: ???

7.Satır: ? İYİ OLACAKLAR ?

8.Satır: MEROY 1884

9:Satır: ??? 1 MAYIS ?

10.Satır: ???

11.Satır: ??? AFYON

12.Satır: KARAHISAR

18 https://team-aow.discuforum.info/t762-Afyonkarahisar-sancagi.htm (E.T.15.03.2020). 


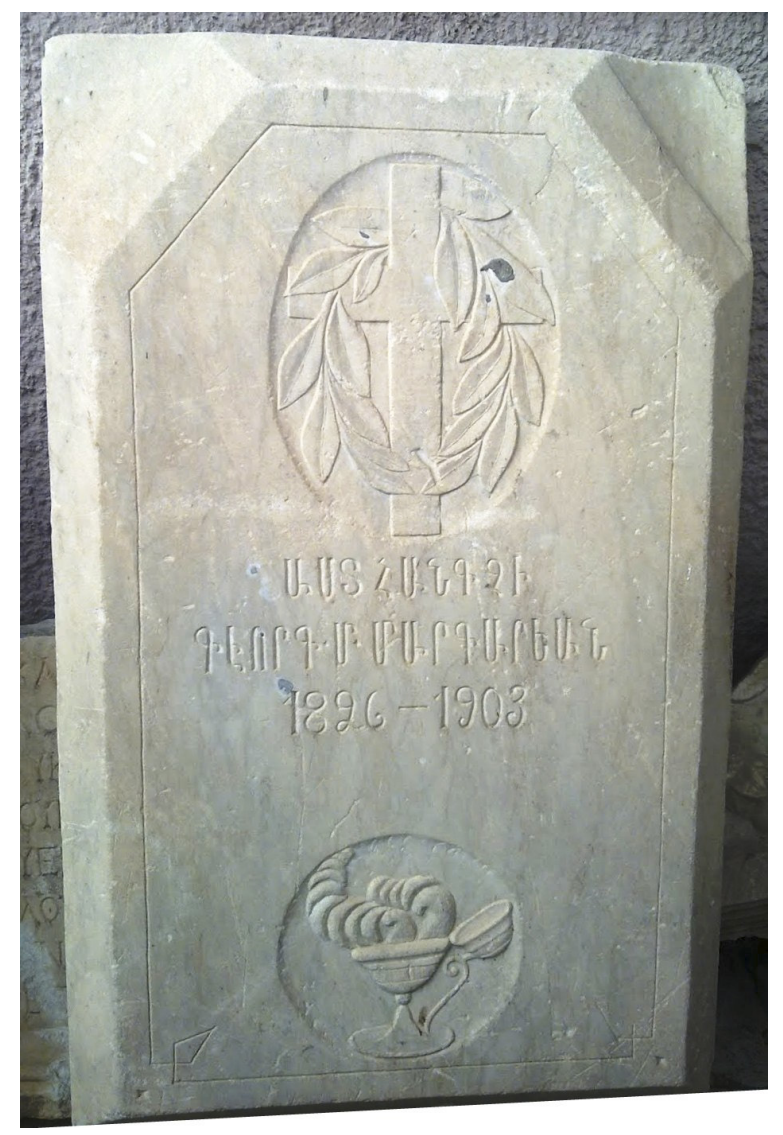

Resim 2: Afyonkarahisar Müzesindeki Ermenice Mezartaşları

\title{
Türkçe Çevirisi:
}

\author{
1.Satır: Burada Dinleniyor \\ 2.Satır: Gevorg M. Markaryan \\ 3.Satır: $1826-1903$
}

Araştırmacılar Afyonkarahisar' daki Ermenilerin Anadolu' daki birçok şehirde yaşayan Ermeni nüfusundan farklı olarak köylerde değil şehirlerde yaşadığını kaydederler. ${ }^{19}$ Afyonkarahisar bölgesindeki Ermeni nüfusunun ağırlıklı olarak sonradan bölgeye gelen kesimden oluştuğunu kaydeden araştırmacılara göre, bu durumun temel nedenleri arasında, Batı Anadolu'daki yerleşik gayrimüslim nüfusunun daha ziyade Rumlardan oluşmasının ilk sırada geldiğine işaret eder. Ermenilerin ise bu bölgeye sonradan gelerek yerleştikleri ifade edilir. Afyonkarahisar ve Batı Anadolu'daki şehirlere sonradan göçle gelen Ermeni nüfusunun ağırlıklı olarak zanaatkâr olmasının ve bölgenin ticari potansiyelinin de bu göçleri tetiklediğini kaydeden Polat, bu durumun aslında Ermeni nüfusunun neden Afyonkarahisar'da köylerde değil de şehirlerde yoğunlaştığı hususuna da açıklık getirdiğini

19 Mehmet İnbaşı, "XVI. Yüzyılda Kayseri ve Civarında Ermeniler”, 21. Yüzyıla Girerken Tarihe Dostça Bir Bakıs; Türk-Ermeni İlişkileri Uluslararası Sempozyumu, Yay. Haz: Berna Türkdoğan, Atatürk Kültür, Dil ve Tarih Yüksek Kurumu Atatürk Araştırma Merkezi Yayınları, Ankara, 2000, s. 53-54'den aktaran Polat 2011 age, s.23. 
kaydeder. ${ }^{20}$

Afyonkarhisar'daki Ermeni nüfusunun değişimi ve özellikle artışında söz konusu dönemlerde yaşanan siyasi ve sosyal gelişmelerin de etkili olduğuna işaret eden Polat'a göre, XVI. yüzyılda İranlılarla yaşanan savaşlar sırasında doğudan batıya ciddi oranda bir Ermeni göçü yaşanmıştır. Yine bölgenin, ilerleyen yıllarda ulaşım noktalarının merkezinde yer alıyor olmasının da bu durumu tetiklediği belirtilmiştir. Savaşların yanı sıra Celali isyanlarının da bölgedeki demografinin yapısını etkileyen faktörler arasında olduğuna işaret eden Polat, bu durumun kitlesel göçlere de neden olduğuna vurgu yapar. Özellikle XVIII. yüzyılda Nadir Şah Afşar döneminde İran'daki Ermenilerin büyük bir kısmının batıya sürüldüğünü ve XIX. yüzyılda ise Osmanl1-Rus savaşlarının bu süreci tetiklediğine işaret eder. ${ }^{21}$

Afyonkarahisar'daki gayrimüslim nüfus açısından Ermenilerin ilk sırada yer aldığına işaret eden Polat, şehirdeki Ermeni nüfusuyla ilgili en eski kayıtların ise XVI. yüzyıla dayandığını ve daha sonrasında ise Evliya Çelebi Seyahatnamesi'nde yer alan rakamların bu konuda önemli ipuçları içerdiğine işaret eder. Buna göre 1671-1672 yıllarında şehre geldiği tahmin edilen Çelebi, burada 4.600 Müslüman, 1.000 de Gayrimüslim hanenin yaşadığını kaydetmiştir. ${ }^{22}$

Afyonkarahisar'la ilgili Tanzimat dönemine dair bazı kayıtların mevcudiyetine de işaret eden Polat, İngiliz Seyyah Hamilton'un 1835-1837 yılları için şehirde 8.400 hanenin yaşadığını kaydettiğini ancak bu rakamların 1831 yılı nüfus sayımına göre oldukça fazla olduğuna yer verir. ${ }^{23}$ XIX. yüzyılda Afyonkarahisar'daki Ermeni nüfusu açısından salnameler de önemli veriler yer almaktadır. 1885 tarihli salnameye göre şehirdeki Ermeni nüfusu 4514'ü yerli, 67'si yabanc1 olmak üzere toplam 4581 Ermeninin yaşadığı kaydedilmiştir. ${ }^{24}$

\section{Sicill-i Ahval Defterleri'ne Göre Afyonkarahisar'da Ermeni Devlet Adamları}

XIX. yüzyılda Osmanlı İmparatorluğu’nda başta İstanbul olmak üzere Anadolu'nun birçok şehrinde yaşayan Ermenilerin toplumsal anlamda yetenekli bir millet oldukları herkes tarafından bilinen bir gerçektir. Benzer bir durum Afyonkarahisar'da da söz konusudur. Buradaki Ermeni nüfusun Müslüman nüfusa oranla son derece kozmopolit bir yapı içerdiğini kaydeden Polat, bu durumun ortaya çıkmasında İmparatorluğun birçok noktasından buraya yapılan göçlerin önemli bir etkisinin olduğuna işaret eder. Afyonkarahisar'a Tokat, Diyarbakır, Sivrihisar, Bursa, Niğde, İstanbul, Kars, Uşak, Urfa, İzmir gibi şehirlerden göçlerin yaşandığını kaydeder. ${ }^{25}$

Ermeni nüfusuna dair önemli bilgiler içeren kayıtlar arasında Ermenilerin yaşadıkları mahallelerin ve bu mahallelere dair bilgilerin yer aldığı kayıtların önemli bir yer vardır. Bu kapsamda Polat, Şer'i mahkemelere yansıyan bilgilerden hareketle XIX. yüzyılda Afyonkarahisar'da Ermenilerin yoğun olarak yaşadıkları mahalleler arasında ilk sırada \% 12,2'lik oranla Surp Toros, \% 8,3'lük oranla Hacı Murad, \% 7,4'lük oranla Tac Ahmet ve \% 6'lık oranlarla Ardıç ve Mecidiye mahallelerinin geldiğini kaydetmiştir. ${ }^{26}$

\footnotetext{
20 Polat 2011, age, s.24.

21 Polat 2011, age, s.32.

22 Çelebi age, s.31-32'den aktaran Polat 2011, age, s.24-25.

23 Polat 2011, age, s.25.

24 Polat 2011, age, s.36-37.

25 Polat 2011, age, s.59.

26 Polat 2011, age, s.53-54.
} 
Afyonkarahisar'da Ermenilerin üst düzey bürokratik görevlerde de yer aldıklarını söylemek mümkündür. Başta Liva İdare Meclisi olmak üzere, adli yönetimde, mahkeme azalıklarında, devlet teşkilatının ve birçok bürokratik kademede görev almışlardır. Ayrıca muhasebecilik, tahsildarlık, sandık eminliği, Ziraat Bankası azalığı gibi ticari görevlerde de bulunmuşlardır. ${ }^{27}$

Osmanlı İmparatorluğu'nda Sicill-i Ahvâl Komisyonu 6 Şubat 1879 tarihinde kurulmuş ve bu tarihten itibaren Devlet bünyesinde görev yapan kişilerin sicil bilgileri kayıt altına alınmaya başlanmıştır. Söz konusu defterlerde 92.137 memurun kayıtlı olduğu ve Karahisar-1 Sahip doğumlu 67 memura ait bilgilere yer verilmiştir. Afyonkarahisar'da görevli 67 devlet memurlarının Kaymakam, Belediye Reisi, Sandık Emini, Müderris, Mücellit, Arzuhalci, Terzi, Değirmenci, Muytap, Tütüncü, Zürra (Çiftçi) vb. meslek gruplarından olan ailelerin çocukları olduğu bilgilerine de yer verilmiştir. Söz konusu 67 devlet memurdan 8'nin Ermeni asıllı olduğu anlaşılmaktadır. ${ }^{28}$

Ermeni devlet adamlarının genel itibariyle Ermenice, Türkçe ve Fransızca dillerini bildikleri, Afyonkarahisar'daki Sıbyan veya İptidai Mekteplerindeki ilk eğitimlerinin ardından Rüştiye ve İdadi Mektepleri'nde eğitimlerini sürdürdükleri anlaşılmaktadır. Ermeni öğrencilerin sancak genelinde gayrimüslimlere mahsus bir idadi bulunmamasından dolayı Müslümanların eğitim gördüğü Afyonkarahisar İdadisi’ne devam ettkileri de kaydedilmiştir. Söz konusu Ermeni devlet adamlarının eğitimini aldıkları okullar arasında özellikle Hukuk, Dârülmulallimîn, Ziraat, Dârülmaarif ve Münşaa gibi okulların ön plana çıktığını söylemek mümkündür. Ermeni öğrencilerin Ermeni, Fransız, Protestan mekteplerinde ilköğrenimini tamamladıktan sonra hem Afyonkarahisar vilâyeti sınırları içinde hem de Anadolu, Rumeli, Arap yarımadası vb. farklı bölgelerde görev yapmışlardır. Görev aldıkları kurumlara genel itibariyle bakıldığında Ziraat Bankası, Düyûnu Umumiye, Posta ve Telgraf İdaresi ile Dâhiliye ve Maliye Nezareti dâhil olmak üzere birçok önemli devlet kurumlarınının olduğunu söylemek mümkündür. ${ }^{29}$

\section{Oseb Efendi}

Karabet Ağa'nın oğlu olarak 1873 yılında Afyonkarahisar'da dünyaya gelen Oseb Efendi, Afyonkarahisar'daki Ermeni Mektebi'nde Türkçe, Ermenice ve Fransızca eğitim görmüştür. Oseb Efendi 23 Temmuz 1898 tarihinde Hudavendigâr Vilâyeti'ndeki Hamidiye Ziraat Mektebinde eğitimini tamamlamış ve Hudavendigâr Vilâyeti Merkez Vergi Tahsilatı Komisyonu'nda Hesap Heyeti'ne 10 ay mülâzım olarak görev almış daha sonra ise 17 Eylül 1900'da 300 kuruş maaşla Tadilat-1 Umumiye Birinci Fırka Muhamminliği’ne tayin olmuştur. ${ }^{30}$

Maliye Nezareti Müsteşarlığı, Ziraat-1 Heyet-i Fenniye ve Bursa Harp Darüttalim Müdüriyetleri'nde de görev alan Oseb Effendi ayrıca Gemlik Kazası Tahsilat Müfettişliği, 19 Ekim 1902'den itibaren ise Gemlik'te çalışmaya başlamıştır. 16 Mart 1903'te Mudanya, 13 Mart 1904'te ise Kütahya Müfettişliğgi'nde görev yapmıştır. ${ }^{31}$

\footnotetext{
27 Ilgar 2014, age, s.19, Polat 2011, age, s.64-65.

28 Aslan 2006, age, s.15-17.

29 Ilgar 2014, age, s.19, Aslan 2006, age, s.16, Polat 2011, age, s.150.

30 BOA, DH. SAID, no. 136, s. 19'dan aktaran Aslan 2006, age, s.106-107.

31 BOA, DH. SAİD, no. 136, s. 19'dan aktaran Aslan 2006, age, s.106-107.
} 


\section{Katipyan Karabet Efendi}

Afyonkarahisar'da görev yapan bir diğer Ermeni devlet adamı Katiplerden Heci Artin Efendi'nin oğlu Katipyan Karabet Efendi'dir. 12 Kasım 1864'te Afyonkarahisar'da dünyaya gelen Karabet Efendi, Ermeni mekteplerinde eğitimini tamamladıktan sonra 12 Mart 1880'de Afyonkarahisar Sancağı Muhasebe Kalemi’nde göreve başlamıştır. 3 Ağustos 1888 yılında 600 kuruş maaşla Aziziye Kazası Mal Müdüriyeti görevine gelen Karabet Efendi, Aziziye Kazası Kaymakamlığı'nda da görev almıştır. 18 Haziran 1892'de Bolvadin Kazası Mal Müdüriyeti'ne tayin olan karabet Efendi, 20 Aralık 1892'de Kirmasti, Mal Müdüriyeti'ne nakledilmiş ve buradaki görevine başlamadan istifa ettiği kaydedilmiştir. ${ }^{32}$

\section{Karabet Efendi}

Osmanlı İmparatorluğu'nda XIX. yüzyılda Afyonkarahisar'da devlet görevinde bulunan bir diğer Ermeni şahsiyet Karabet Efendi'dir. Terzi Sarafyan Kigork Ağa’nın oğlu olan Karabet Efendi 18 Mart 1859'de Afyonkarahisar'da dünyaya gelmiştir. Mahallenin Sibyan ve Ermeni Rüştiye Mektepleri'nde eğitim alan Karabet Efendi, Türkçe ve Ermeniceyi iyi derecede bilen bir memurdur. 1 Temmuz 1882'de Afyonkarahisar Tahrirat Kalemi’nde mülâzım olarak göreve başlamıştır. 12 Temmuz 1882-12 Mart 1885 yılları arasında Şuhut Nahiyesi Muvakkat Aşar Kitabetleri'yle, Sermuharrirliği'nde görev yapmıştır. 27 Mayıs 1885 yılına gelindiğinde Hanbarçin Aşar Memuriyeti'nde göreve başlamıştır. 10 Temmuz 1906'da kendi isteğiyle Karabet Efendi'nin 8 Nisan 1890'da Düyun-1 Umumiye Müdüriyeti İkinci Kitabeti'ne nakledildiği ve 14 Ocak 190119 Ekim 1902 tarihleri arasında, mezkûr Emanet Vekâleti’ni ilave ikinci görev olarak yaptığı kaydedilmiştir. ${ }^{33}$

\section{Kigork Efendi}

XIX. yüzyılda Afyonkarahisar'da devlet memuriyetinde bulunan bir diğer isim ise Kigork Efendi'dir. Baba adı Heci Artin Efendi olan Kigork Efendi 6 Temmuz 1866'da Afyonkarahisar' da dünyaya gelmiştir. Diğer meslektaşları gibi Ermeni Sıbyan Mektebi’nde Türkçe ve Ermenice eğitim almıştır. 3 Ağustos 1882'de Afyonkarahisar Sancağı Hayvan Pazarı Müfettişliği görevine getirilmiş ancak 13 Mart 1885 yılında bu görevden ayrılmıştır. 14 A ğustos 1885 yılında Aşar İdaresi Kitabeti görevine getirilen Kigork Efendi 2 Mart 1887'de memuriyetinin lağvedilmiş olması nedeniyle bir süre açıkta kalmış daha sonra Muhasebe Kalemine mülâzım olarak atanmıştır. 5 Ağustos 1887'de Aşar Ambar Kitabeti'ne tayin olan Kigork Efendi 26 Haziran 1889'da buradaki görevinin sona ermesiyle açıkta kalmış ve yeniden Muhasebe-i Liva'ya mülâzım olarak geri dönmüştür. 9 Mart 1889 yılında Bolvadin Kazası Ağnam Tadat Kol MuharrirliğI görevine getirilmiştir. 13 Eylül 1889-27 Şubat 1890 yılları arasında Afyonkarahisar Aşar, 10 Mart 1890'da ise Merkez Ağnam Tahsilat Kitabetleri görevlerini yerine getirmiştir. 24 Mayıs 1890 yılında Muhasebe Kalemi Merkez Kitabeti'ne getirilen Kigork Efendi 26 Kasım 1892'de Muhasebe Kalemi Başkitabeti'ne getirilmiştir. ${ }^{34}$

\footnotetext{
32 BOA, DH. SAID, no.30, s.79'den aktaran Aslan 2006, age, s.66.

33 BOA, DH. SAID, no. 138, s. 307'den aktaran Aslan 2006, age, s.67.

34 BOA, DH. SAID, no. 41, s. 45'den aktaran Aslan 2006, age, s.68.
} 


\section{İstepan Efendi}

Sicill-i Ahval Defterleri'nde kayıtlı Ermeni memurlardan İstepan Efendi ise Karabet Ağa'nın oğludur. 1860'de Afyonkarahisar'da dünyaya gelen İstepan Efendi diğer meslektaşları gibi ilk eğitimini Ermeni Mekteplerinde almıştır. Ermenice ve Türkçe bilen İstepan Efendi iki yıl Afyonkarahisar Sancağı Arazi Kalemi görevinde bulunduğu kaydedilmiştir. Daha sonra Aşar İdaresinde mülâzım olarak, 21 Ocak 1300'de ise Aziziye Kazası Aşar ve Ağnam Başkitâbeti görevine tayin olmuştur. 1886 yılında Aşar İdareleri'nin kaldırılmasıyla birlikte açıkta kaldığı kaydedilen İstepan Efendi'nin görevini yerine getirmeyle ilgili bazı sıkıntıların ortaya çıktığı görülmektedir. Memuriyeti sırasında köylülerden emanet aşarı, afyon ve göğeri (sebze) bedellerinden haksız para aldığı ve bu konuda kendisinin ihbar edildiği bilgilerine de yer verildiği görülmektedir. Bu konuyla ilgili olarak Aziziye Bidâyet Mahkemesi tarafından bir soruşturma yapıldıktan sonra altı ay hapisle cezalandırıldığı ancak daha sonra Afyonkarahisar Sancağı Meclis İdaresi tarafından yeniden yapılan yargılama sonucunda berat ettiği kaydedilmiştir. Daha sonra 1887-1888 yılları arasında Kitâbet-i Hususisi ve Bolvadin Kazası Aşar-1 Ambar Memurluğu gibi görevlerde de bulunmuştur. 1889 yılında ise Afyonkarahisar Banka Şubesi Ambar Emaneti'ne tayin olan İstepan Efendi'nin bu görevinin idare tarafından kabul edilmemesi nedeniyle 1890'da aynı bankanın kitâbetine tayin olmuştur. 1894 yılında ise Afyonkarahisar Şubesi Memur Muavinliği görevine getirilmiştir. Söz konusu banka şubesinin teftişi sonucu daha önce görevden azledilen şubenin eski memurunun zimmet, haksız kazanç ve yolsuzluklarını bildiği halde ilgili yetkiliye haber vermemesi nedeniyle 1896'da bu görevinden azledilmiştir. Bir müddet açıkta kaldıktan sonra 12 Kasım 1897'de yeniden Akhisar Kazası Ziraat Bankası Sandığg Muhasebe Kitâbeti görevien gelen İstepan Efendi, 1 Ekim 1901 'de 650 kuruş maaşla Uşak Kazası Banka Sandığ1 Muhasebe Kitâbeti görevine getirilmiştir. ${ }^{35}$ İstepan Efendi'nin memuriyeti boyunca çalıştığı kurumlar, görev süreleri, tayin ve azil nedenleri, aldığ1 maaş miktarları, aldığı ödüller ve görev yaptığ Sicill-i Ahval Defterleri bu yönüyle oldukça kapsamlı veriler içerdiğini söylemek mümkündür.

\section{Onnik Efendi}

Sicill-i Ahval Defterleri'nde kayıtlı bir diğer Ermeni devlet memuru ise Onnik Ohannes Efendi'dir. 1884/1885'te yılında Afyonkarahisar'da dünyaya gelen Onnik Efendi, ilk eğitimini Millet mektebinde, daha sonra Konya'da Protestan, Eskişehir'de ise Fransız Mektepleri'nde tamamlamıştır. Türkçe ve Fransızca dillerine vakıf Onnik Efendi, 13 Nisan 1908'de Selanik Vilâyeti'nde Kavala Telgraf ve Posta Merkezi Muhaberatı Ecnebiye Memurluğu görevinde bulunmuştur. Onnik Efendi'nin bu görevi dönemin Telgraf ve Posta Nezareti Makamı tarafından onaylanmıştır. ${ }^{36}$

\section{Ohannes Efendi}

XIX. yüzyılda Afyonkarahisar'da Devlet görevinde bulunan bir diğer Ermeni memur ise Serkiz Işılyan'ın oğlu 2 Mayıs 1836 Afyonkarahisar doğumlu Ohannes Efendi'dir. 1857/1858'deAfyonkarahisar Sancağı Sandık Sarraflığı görevine getirilen Ohannes Efendi burada 8 ay görev yaptıktan sonra istifa etmiştir. Sicill-i Ahval DEfeterleri'nde 1867/1868'de Ticaret Mahkemesi Azayı Muvakkatası görevine getirildiği, 1869/1870'de ise Mülga Temyiz-i Hukuk Meclis Azası olduğu kaydedilmiştir. Ohannes Efendi 1877'de Ticaret Mahkemesi Aza-y1 Mütemadiyesi (Daimi Azası) görevine getirilmiş, 16 Şubat 1885 'te ise Ticaret Mahkemesi Riyaseti başkanı olmuştur.

35 BOA, DH. SAİ, no. 162, s. 279'dan aktaran Aslan 2006, age, s.63-65.

36 BOA, DH. SAID, no. 161, s. 19'den aktaran Aslan 2006, age, s.105. 
Ohannes Efendi'nin devlet görevleri sırasında zorunluluktan kaynaklı istifaları nedeniyle sorumlu tutulmadığı, Afyonkarahisar Mutasarrıfı İbrahim Sarım Beyefendi'nin Ohannes Efendi'nin görevini layıkıyla yerine getirdiğine dair kayıtların da tutulduğu anlaşılmaktadır. Bu durumun neticesi olarak Ohannes Efendi'nin 20 Mart 1888'de Rütbe-i Salise ile taltif edildiği de Sicill-i Ahval Defterleri'ne yansıdığı görülmektedir. ${ }^{37}$

\section{Nersesyan Agop Efendi}

Osmanlı İmparatorluğu'nda Afyonkarahisar'da görev yapmış bir diğer Ermeni Devlet adamı ise Kivork Ağa'nın oğlu Nersesyan Agop Efendi' dir. 1861/1862'de Afyonkarahisar' da dünyaya gelen Agop Efendi, diğer meslektaşları gibi Ermeni mekteplerinde eğitim almıştır. Ermenice, Türkçe ve Fransızca dillerine vakıf olan Agop Efendi bir süre Afyonkarahisar Sancağı Aşar İdaresi'nde görev yapmıştır. 14 Ağustos 1880'de Dazkırı Nahiyesi Afyon (haşhaş) Muharrirliği, aynı sene Gebeceler ve Feleli, 1881 yılından itibaren ise Salar ve Süğlün, 1883'ten itibaren de Arızlı ve Karaca köylerinde Aşar MuharrirliğI görevlerinde bulunduğu kaydedilmiştir. 1884'de ise Eğret ve Susuz Köyü Afyon (haşhaş) Muharrirliği görevlerinde bulunduğu kaydedilmiştir. 1886'ya gelindiğinde Çal Kazası Aşar Ambar Emaneti görevine getirilen Agop Efendi 3 Nisan 1886'da görevinin ilga edilmesi nedeniyle bu görevden ayrılmıştır. 6 Kasım 1886-1893 yılları arasında farklı ücretler karşılığında Afyonkarahisar Köyleri Afyon (haşhaş) Kol MuharrirliğI görevlerinde de bulunmuştur. 1 Aralık 1894 yılında Sandıklı Ziraat Bankası Sandığı Muhasebe Kitabeti Refakati'ne tayin edildiği anlaşılan Agop Efendi daha sonra 1896'da ise Bolvadin Ziraat Bankası Sandığ Muhasebe Kitabeti görevine getirilmiştir. 29 Kasım 1903'te Afyonkarahisar Ziraat Bankası Şubesi Katibi Saniliği'ne gelen Agop Efendi, 13 Ocak 1904'te Katibi Evvelliği’ne, 14 Şubat 1908'de ise İkrazat Sandığında görevlendirilmiştir. Agop Efendi'nin Devlet hizmetinde yaptığı görevler, görev süreleri, aldığı maaşlar, görev değişim nedenleri vb. hususlara dair ayrıntılı kayıtların yer aldığı Sicill-i Ahval Defteleri'nde yer aldığ 1 görülmektedir. ${ }^{38}$

\section{Sonuç}

Sonuç olarak XIX. yüzyılda Afyonkarahisar'da Anadolu'nun birçok bölgesinde olduğu üzere yoğun bir Ermeni nüfusunun varlığından bahsetmek mümkündür. Ancak buradaki nüfusun diğer yörelerdeki Ermenilerden farklı olarak başka bölgelerden buraya geldikleri anlaşılmaktadır. $\mathrm{Bu}$ durumun yaşanmasında Ermenilerin toplumsal anlamda zanaatkâr bir millet olmalarının yanı sıra İmparatorluk sınırları içinde ve dışında yaşanan siyasi ve sosyal gelişmeler ile savaşların etkin rol oynadığından bahsetmek mümkündür. Bu kapsamda XIX. yüzyılda Afyonkarahisar'da görev yapan Ermeni devlet adamlarına dair en önemli birincil kaynakların Sicill-i Ahval Defterleri olduğunu söylemek gerekir. Nitekim Sicill-i Ahval Defterlerinde Afyonkarahisar'da doğmuş Ermeni devlet adamlarının hem ailevi bilgilerine hem de görev aldıkları kurumlara dair ayrıntılı bilgilere yer verilmiştir. Bu noktada söz konusu devlet adamlarının hangi eğitimleri aldıkları, bildikleri yabancı diller ve görev aldıkları şehirlere ve aldıkları maaşlara dair de kapsamlı bilgilerin yer aldığını söylemek mümkündür.

Ermeni devlet adamları Ermeni entelektüellerden farklı olarak kaleme aldıkları herhangi bir eser veya icra ettikleri sanatsal bir çalışma olmadığından kendileriyle ilgili yegâne kaynak Sicill-i

\footnotetext{
37 BOA, DH. SAİ, no. 18, s. 43'den aktaran Aslan 2006, age, s.104.

38 BOA, DH. SAID, no. 196, s. 259'den aktaran Aslan 2006, age, s.102-103.
} 
Ahval Defterleri olmuştur. Bu nedenle neredeyse tüm hayatlarına dair en önemli ve yegane bilgi kaynağı olan bu defterlerde aldıkları eğitim, ailelerinin kökeni, görev yaptıkları kurumlara dair ayrıntılı bilgilerin olduğu görülmektedir. Ancak Sicill-i Ahval Defterleri’nde söz konusu Ermeni devlet adamlarının dini durumuna dair herhangi bir kayda rastlanmamıştır. Nitekim konuyla ilgili yapılan çalışmalara bakıldığında Afyonkarahisar'da Katolik, Protestan ve Gregoryen Ermeni nüfusunun mevcudiyetine dair Salnamelerde bilgilerin olduğu da görülmektedir.

\section{Kaynaklar}

“Afyonkarahisar Sancağı”,

https://team-aow.discuforum.info/t762-Afyonkarahisar-sancagi.htm (E.T.15.03.2020)

Artinian, Vartan (2004). Osmanlı Devleti'nde Ermeni Anayasası'nın Doğuşu 1839-1863. İstanbul: Aras Yayınları.

Aslan, Ahmet (2006). Sicill-i Ahvâl defterlerine göre Osmanlı döneminde Afyonkarahisarlı Devlet Memurları (1879-1909). Yüksek Lisans Tezi. Muğla: Muğla Üniversitesi.

Aslan, Kevork (2005). Armenia and The Armenians. New York: Elibron Classics.

Atabek, Ömer Fevzi (1997). Afyon Vilayeti Tarihçesi. Haz: Turan Akkoyun. Afyon: AKÜ Yayınlar1.

Barsoumian, Hagop (1982). "The dual role of the Armenian Amira class within the Ottoman government and the Armenian millet (1750-1850)". Christians and Jews in the Ottoman Empire: the Functioning of a Plural Society, Haz: B. Braude, B.\&B. Lewis, Cilt 1, New York-Londra: Princeton University. s.171-184.

Benjamin Braude, \& Bernard Lewis (Eds.), Christians and Jews in the Ottoman Empire: The Functioning of a Plural Society (Vol. 2), Holmes \& Meier Pub., 1982, London.

BOA, DH. SAID, no. 136.

BOA, DH. SAID, no.30.

BOA, DH. SAİ, no. 138.

BOA, DH. SAİD, no. 41.

BA, DH. SAİ, no. 162.

BOA, DH. SAİD, no. 18.

BOA, DH. SAID, no. 196.

Çark, Yervant G. (1953). Türk Devleti Hizmetinde Ermeniler. İstanbul: Kesit Yayınları.

Dahiliye Nezareti Sicill-i Ahvâl İdare-i Umûmiyyesi (BOA, DH.SAID)

Daşdemir, Latif (2001). "Afyonkarahisar"da Türk Yerleşim ve Nüfusu”. Afyonkarahisar Kütüğ̈̈, C. I, Afyon: AKÜ Yay.

Evliya Çelebi Seyahatnamesi (1935). Anadolu, Suriye, Hicaz 1671-1672, C. IX. İstanbul: İstanbul (Devlet Matbaasi).

Edmund M., Herzig, The Armenian Merchants of New Julfa, Isfahan: A Study in Pre-modern Asian Trade. UK: Oxford University, 1991. 
Ilgar, Yusuf(2005). “Afyonkarahisar Ermenilerinde Kültürel ve Dinî Hayat”. Sosyal Bilimler Dergisi, C. 7, S. 1, s. 240-265. s.1-21. (2014). “Afyonkarahisar Ermenileri Üzerine Bir Deneme”. Yeni Türkiye, C. 60,

İnbaşı, Mehmet (2000). "XVI. Yüzyıl"eda Kayseri ve Civarında Ermeniler”. 21. Yüzyıla Girerken Tarihe Dostça Bir Bakış: Türk-Ermeni İlişkileri Uluslararası Sempozyumu. Yay. Haz: Berna Türkdoğan. Ankara: Atatürk Kültür, Dil ve Tarih Yüksek Kurumu Atatürk Araştırma Merkezi Yayınları, s. 47-62. Yayınlar1.

Koçaş, M. Sadi (1990). Tarihte Ermeniler ve Türk-Ermeni İlişkileri. İstanbul: Kastaş

Kouyoumjian, Hratch (2016). Ethnic Armenian Civil Servants in the Ottoman Empire in 1909. Great Britain: Armenian Genocide Centenary Commemoration Committee.

Krikorian, Mesrob K. (1997). Armenians in the Service of the Ottoman Empire: 1860-1908, London \& NewYork: Routledge.

Oshagan, Vahe (1999). "From Enlightenment to Renaissance: The Armenian Experience". Enlightenment and Diaspora, The Armenian and Jewish Cases. Edt: Richard G. Hovannisian and David N. Myers. Atlanta, Georgia: Scholor Press. s.145-180.

Polat, Zelkif(2011). Tanzimattan Tanzimat'tan Cumhuriyet'e Afyonkarahisar'da Ermengiler (1839-1923). Doktora Tezi. Afyonkarahisar: Afyon Kocatepe Üniversitesi.

Sarısaman, Sadık (2007). “Afyonkarahisar’da Ermeniler 1910-1914 (Şeriyye Sicillerine Göre). Hoşgörü Toplumunda Ermeniler, C. IV. Der: Metin Hülagü, Gülbadi Alan, Süleyman Demirel, Şakir Batmaz, Kayseri: Erciyes Üniversitesi Yayınları, C. 3, s. 91-118.

Simeon (1999). Tarihte Ermeniler. Çev: Hrand D. Andreasyan. İstanbul: Çiviyazıları.

Yarman Arsen ve Ara Aginyan (2013). Sultan II. Mahmut ve Kazaz Artin Amira. İstanbul: Surp Pirgiç Kültür Sanat Yayınları.

Zeidner, Robert F. (1976) "Britain and the Launching of the Armenian Question". International Journal of Middle East Studies, C. 7, S. 4, s. 465-483. 